\title{
Effect of moisture content on specific cutting energy consumption in Corymbia citriodora and Eucalyptus urophylla woods
}

\author{
Efeito da umidade no consumo de energia específica de corte \\ de madeiras de Corymbia citriodora e Eucalyptus urophylla
}

\author{
Débora Fernanda Reis Nascimento ${ }^{1}$, Luiz Eduardo de Lima Melo², \\ José Reinaldo Moreira da Silva ${ }^{3}$, Paulo Fernando Trugilho ${ }^{4}$ e Alfredo Napoli ${ }^{4}$
}

\begin{abstract}
Resumo
Foram estudados os efeitos de diferentes umidades sobre o consumo da energia específica de corte longitudinal $\left(90-0^{\circ}\right)$ em madeiras de Eucalyptus urophylla S.T. Blake e Corymbia citriodora Hill \& Johnson. As tábuas foram submetidas, em triplicata, a três diferentes umidades: $2 \%$ (seca em estufa), $12 \%$ (equilíbrio em sala de climatização) e $75 \%$ (saturada submersão em água). As amostras foram cortadas em serra circular devidamente preparada para registrar o consumo de energia do corte longitudinal. Os dados obtidos foram submetidos a análise de variância e teste de média de Scott-Knott, a 5\% de significância. Os resultados mostraram não haver influência da espécie sobre a energia específica de corte. Já a umidade, influencia significativamente a energia específica de corte. Houve aumento de $44 \%$ no consumo da energia específica de corte com a redução da umidade de $75 \%$ (condição saturada) para $12 \%$ (condição de equilíbrio) e redução de $54 \%$ do consumo da energia de quando a madeira secou de $12 \%$ para $2 \%$ (condição seca) de umidade.
\end{abstract}

Palavras-chave: usinagem da madeira, corte $90^{\circ}-0^{\circ}$, teor de umidade da madeira, força de corte.

\begin{abstract}
The effects of various moisture conditions on the specific cutting energy of the longitudinal cut $\left(90^{\circ}-0^{\circ}\right)$ in Eucalyptus urophylla S.T. Blake and Corymbia citriodora Hill \& Johnson were studied. The boards were submitted, in triplicate, to three different moisture contents: $2 \%$ (kiln dried), $12 \%$ (equilibrium moisture content in an air conditioning room) and $75 \%$ (saturated in water submersion). The material was processed with a circular saw to obtain the specific cutting energy consumption of the longitudinal cut $\left(90^{\circ}-0^{\circ}\right)$. The data obtained were submitted to analysis of variance, $\mathrm{F}$ test and Scott-Knott test, at $5 \%$ of significance. The results showed no influence of the species on the specific cutting energy. However, the moisture content significantly influences the specific cutting energy .There was a $44 \%$ increase in the specific cutting energy consumption with moisture content reduced from $75 \%$ (saturated condition) to $12 \%$ (equilibrium condition) and $54 \%$ reduction in cutting force when wood dried from $12 \%$ to $2 \%$ (dry condition) moisture.
\end{abstract}

Keywords: machining of wood, cut $90^{\circ}-0^{\circ}$, wood moisture content, cutting force.

\section{INTRODUCTION}

As a biological material wood has a complex and variable structure. Various properties of wood can influence the cutting process, so the understanding of the interaction between tools and raw material can be reflected in energy efficiency during the various mechanical steps of wood processing.

Knowledge of the behavior of wood during machining is a necessity linked to processing within wood industries, mainly for economic and productive reasons. Machinery and tools manufactured for wood processing, as well as their handlers, need reliable information about the main factors that influence the cut and its variations under different situations (EYMA et al., 2004).

\footnotetext{
${ }^{1}$ Granduanda em Engenharia Florestal. UFLA - Universidade Federal de Lavras. Campus Universitário - Caixa Postal 3037 - 37200-000 - Lavras, MG, Brasil. E-mail: deborafrnascimento@gmail.com

2Professor Associado do Departamento de Tecnologia e Recursos Naturais. UEPA - Universidade do Estado do Pará - Av. Hiléia, s/n - Caixa Postal: 09 - 68503120 - Marabá, PA, Brasil. E-mail: luizeduardo.limamelo@gmail.com

3Professor Titular do Departamento de Engenharia Florestal. UFLA - Universidade Federal de Lavras. Campus Universitário - Caixa Postal 3037 - 37200-000 - Lavras, MG, Brasil. E-mail: jreinaldo@dcf.ufla.br

${ }^{4}$ Professor Titular do Departamento de Engenharia Florestal. UFLA - Universidade Federal de Lavras. Campus Universitário - Caixa Postal 3037 - 37200-000 - Lavras, MG, Brasil. E-mail: trugilho@dcf.ufla.br
} 
Nascimento et al. - Effect of moisture content on specific cutting energy

consumption in Corymbia citriodora and Eucalyptus urophylla woods

The wood moisture content and the density are the main characteristics that influence the cut. In general, studies that have focused on the interaction between wood moisture and the forces involved in the cutting process, report that there is a downward trend of cutting forces due to the increase of wood moisture (FRANZ, 1958; KOCH, 1964; LU I et al., 2004; MORADPOUR et al., 2013). However, variations in this behavior may occur depending on the species and moisture conditions used (LOEHNERTZ; COOZ, 1998). The influence of moisture on the forces involved in the cutting process is not fully understood. This is mainly because the unpredictable variability of other wood properties impedes the establishment of precise relationships among these factors, as well as the difficulty of maintaining the moisture content of wood during mechanical processing due to its hygroscopicity. It was also found that studies of the interaction between cutting force and moisture have been conducted within the wood moisture range between the equilibrium condition (approximately $12 \%$ ) and saturated wood (above $28 \%$ ).

The aim of this study was to determine the effect of moisture on the specific cutting energy consumption in the longitudinal cut $\left(90^{\circ}-0^{\circ}\right)$ of Corymbia citriodora Hill \& Johnson and Eucalyptus urophylla S.T. Blake woods under the conditions of moisture, dry, saturated and equilibrium.

\section{MATERIAL AND METHODS}

Two species were analyzed, seven years of age: Corymbia citriodora Hill \& Johnson, from seed planting of Cenibra S.A. and Eucalyptus urophylla S.T. Blake (MN 463 clone) from commercial plantations of the V \& M Florestal Ltda. Mean apparent wood densities (12\%) were 0.72 and $0.70 \mathrm{~g} . \mathrm{cm}^{-3}$, for C. citriodora and E. urophylla, respectively.

Central long boards, of $80 \mathrm{~cm}$ in length, from three trees of each species were sampled. The boards were processed on a band saw and planed, resulting in three boards of $74 \times 18 \times 2 \mathrm{~cm}$ (length $\mathrm{x}$ width $\mathrm{x}$ thickness) for each evaluated moisture content for each species. The specimens were subjected to three moisture condition stabilizations: drying in an oven at $100^{\circ} \mathrm{C}$ to achieve the dry condition, conditioning in a climatic chamber at $20^{\circ} \mathrm{C} / 65 \%$ relative humidity to achieve the equilibrium condition and immersion in water to achieve the saturated condition.

The boards, submitted to drying in a forced-air circulation oven, were clamped in order to reduce possible drying defects. The initial temperature was $50^{\circ} \mathrm{C}$, for 12 hours, but every 2 hours the clamps were adjusted. On the second day, the temperature was raised by $10^{\circ} \mathrm{C}$, every 2 hours, up to $103 \pm 2{ }^{\circ} \mathrm{C}$ being kept at this temperature until reaching constant weight. This last stage lasted approximately 48 hours and the total time of the drying process was three days. The boards subjected to air conditioning were placed into the conditioning chamber at a temperature of $20 \pm 3^{\circ} \mathrm{C}$ and relative humidity of $65 \pm 5 \%$ until mass stabilization. For the evaluation of wood in the green condition, the boards were immersed in water in a closed chamber with mass gain monitoring until stabilization. The total time of this procedure was 40 days. The mean moisture content established after each condition and during mechanical processing was: dry condition $2 \%(1-2 \%), 12 \%$ equilibrium condition (11-13\%) and 75\% saturated condition (56-97\%).

In order to obtain the longitudinal cut $\left(90^{\circ}-0^{\circ}\right)$ specific cutting energy consumption, the material was machined on a trolly circular saw, $7.5 \mathrm{CV}$, with a forwarding and cutting speed control system. A $400 \mathrm{~mm}$ diameter circular saw blade was used with 24 alternate teeth, WZ profile, with $5 \mathrm{~mm}$ thickness and no tooth wear. The table was adapted associated with pneumatic pistons for fixing the material, which allowed side movement of the test bodies. This adaptation enabled the cuts to be made at specific points of the wood and made the machining operation safe. On average, 20 cuts were made on each board. The cut thickness established was similar to that of the circular saw tooth (5 mm) (Figure 1 and 2), to minimize possible effects of internal tension, as suggested by Melo et al. (2015). 


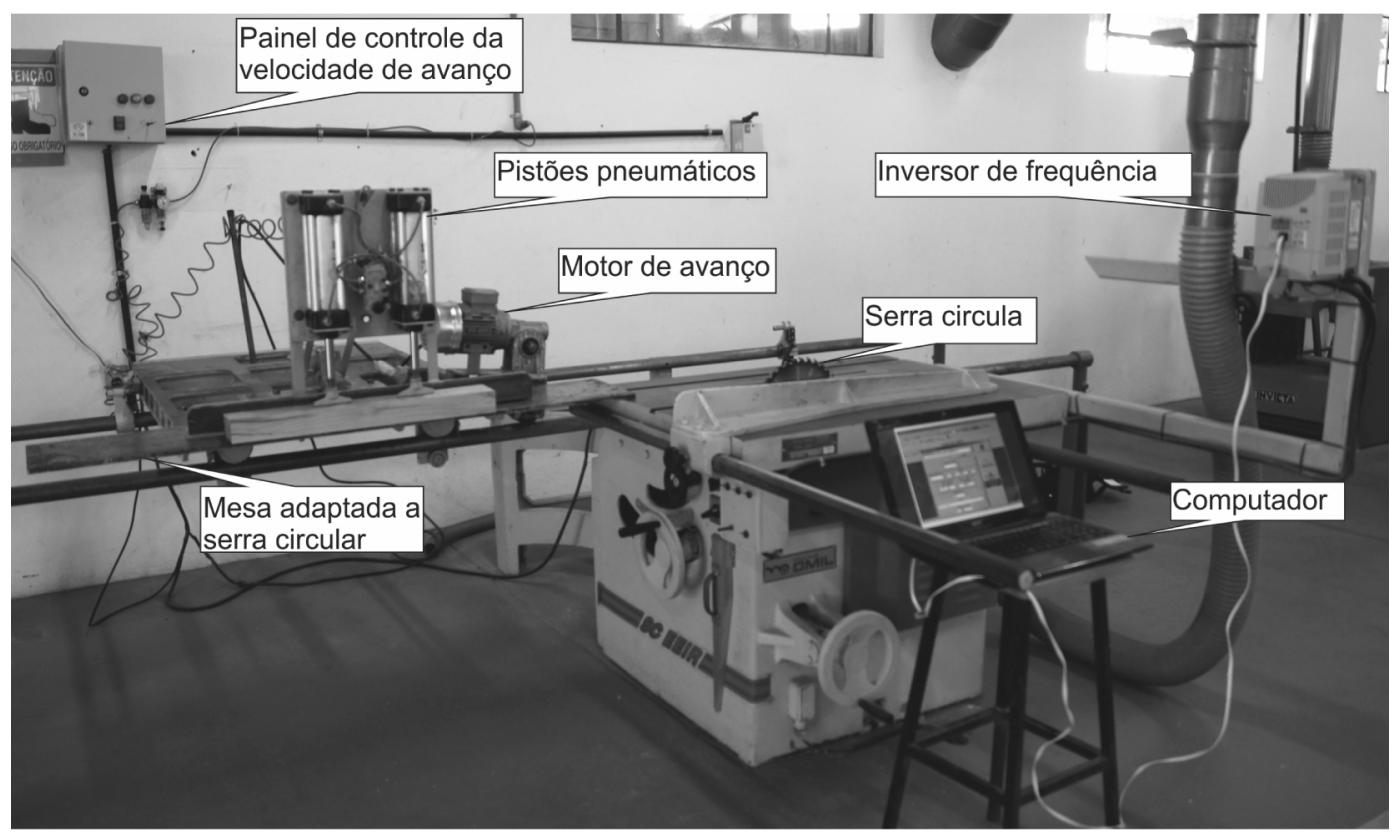

Figure 1. Setup used for data processing and acquisition.

Figura 1. Organização dos equipamentos utilizados para processamento e aquisição de dados.

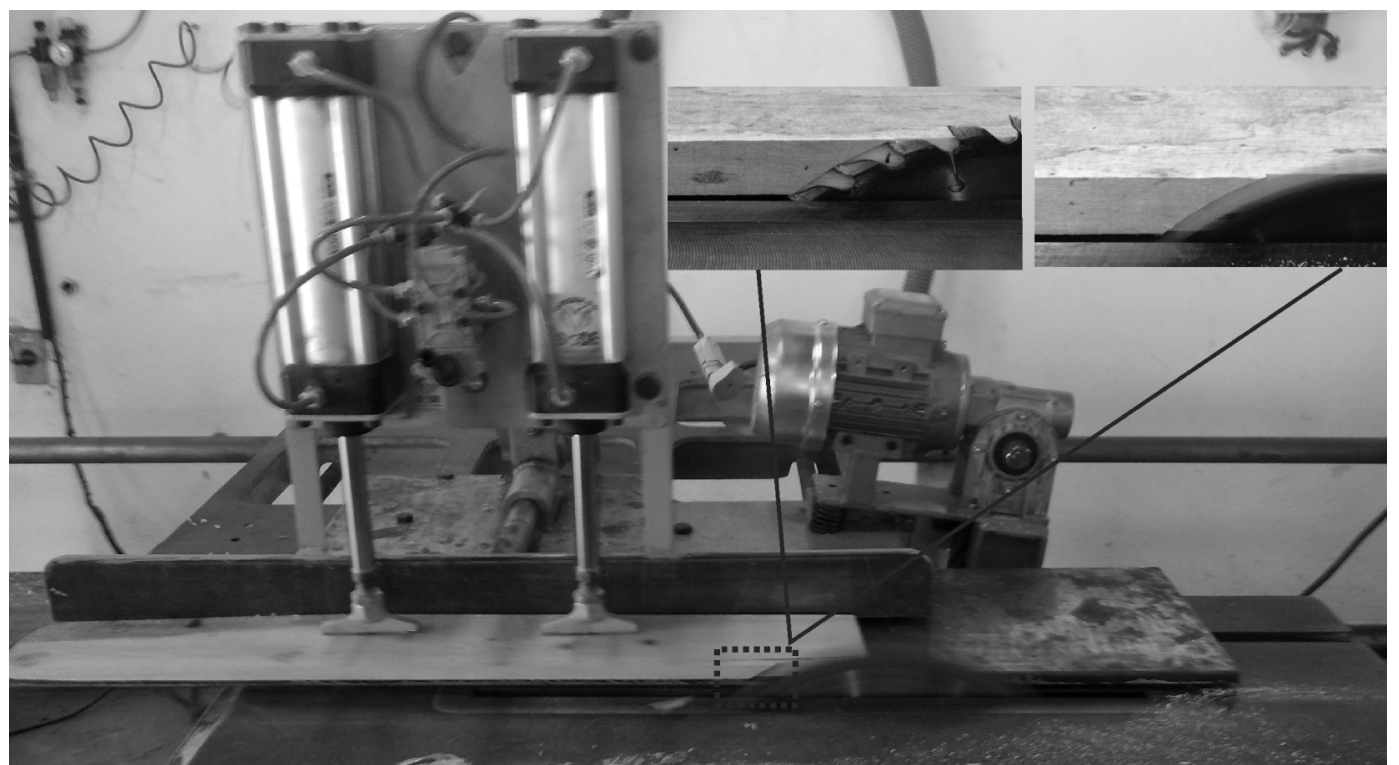

Figure 2. Mechanical processing of the material showing the cutting performed with $5 \mathrm{~mm}$ thickness (dotted square). Figura 2. Processamento mecânico da madeira evidenciando o corte realizado com $5 \mathrm{~mm}$ de espessura (quadrado tracejado).

During the cutting, the feed speed was $10 \mathrm{~m} \cdot \mathrm{min}^{-1}$ and the cutting speed was $21 \mathrm{~m} . \mathrm{s}^{-1}$, corresponding to an average rotation of $1000 \mathrm{rpm}$ and the maximum instantaneous torque was 92.5 N.m, lasting $4.65 \mathrm{~s}$. Thus, the specific cutting energy $\left(\mathrm{J} . \mathrm{cm}^{-3}\right)$ was determined by the instantaneous measurements of torque (N.m) and the motor shaft speed (rpm). The data acquisition frequency (speed and torque) was $4 \mathrm{~Hz}$. The collection and storage of the material processing electrical parameters were conducted through a WEG frequency inverter, CFW 08 model, equipped with serial communication interface (KSD CFW08) and Super Drive software (software programming of WEG drives) attached to the computer (Figure 1). The communication between the frequency inverter and microcomputer was made via the serial interface module RS-232 PC/Drive. For parameterization and monitoring of frequency inverter data, we used the software Super Drive. For that, value proportio- 
Nascimento et al. - Effect of moisture content on specific cutting energy

consumption in Corymbia citriodora and Eucalyptus urophylla woods

nal to frequency (rpm), motor output currents (Ampere), the motor output voltage (Volts) and motor torque (\%) were simultaneously acquired. For the calculation of specific cutting energy $\left(\mathrm{J} . \mathrm{cm}^{-3}\right)$, instantaneous power curves were determined according to Equation 1:

$$
P_{\text {instantaneous }}=T_{i} \times n_{i} \quad \text { (Equation 1) }
$$

In which:

$\mathrm{P}_{\text {instantaneous }}=$ instantaneous power $(\mathrm{W})$;

$\mathrm{T}_{\mathrm{i}}=$ instantaneous motor torque (N.m);

$\mathrm{n}_{\mathrm{i}}=$ instantaneous rotation speed (rpm).

Subsequently, there was integration of the instantaneous power curves related to the time to calculate the total energy $(\mathrm{J})$ according to Equation 2:

$$
E_{\text {Total }}=\int_{0}^{t} P_{\text {instantaneous }} \times d t \quad \text { (Equation 2) }
$$

In which:

$\mathrm{E}_{\text {Total }}=$ total cutting force $(\mathrm{J})$;

$\mathrm{dt}=$ time in seconds.

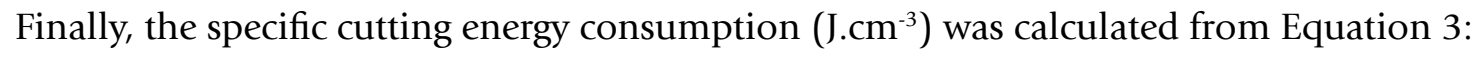

$$
E_{s}=\frac{E_{\text {total }}}{c \times e \times k} \quad \text { (Equation 3) }
$$

In which:

$\mathrm{E}_{\mathrm{s}}=$ specific cutting energy $\left(\mathrm{J} \cdot \mathrm{cm}^{-3}\right)$;

$\mathrm{c}=$ length of test specimen $(\mathrm{cm})$;

$\mathrm{e}=$ thickness of test specimen $(\mathrm{cm})$;

$\mathrm{k}=$ thickness of the tool tooth $(\mathrm{cm})$.

From the results obtained analyses of variance (ANOVA) were carried out considering the completely randomized design in a factorial scheme. The factors analyzed by the F-test were species and moisture content and for multiple comparisons of means the average test Scott-Knott was used, at $5 \%$ of significance.

\section{RESULTS AND DISCUSSION}

Table 1 presents the mean specific cutting energy values for each species evaluated within each of the tested moisture treatments.

\begin{tabular}{|c|c|c|c|}
\hline \multirow{2}{*}{ Species } & \multicolumn{3}{|c|}{ Specific cutting energy $\left({\left.\mathrm{J} . \mathrm{cm}^{-3}\right)}^{-}\right.$} \\
\hline & Dry & Equilibrium & Saturated \\
\hline C. citriodora & $5.4(1.9)^{*}$ & $7.0(2.1)$ & $6.1(0.8)$ \\
\hline E. urophylla & $5.0(1.9)$ & $10.9(2.1)$ & $7.6(0.5)$ \\
\hline
\end{tabular}

Table 1. Mean specific cutting energy values of each tested moisture condition for each species.

Tabela 1. Densidade básica, retração e anisotropia obtidas para a madeira de Eucalyptus sp.

* represents the standard error of the data.

Table 2 presents a summary of the analysis of variance. It was observed that the effect of the species and the interaction between species and moisture content were not significant, at $5 \%$ of significance, by the F-test. For specific cutting energy, no significant interaction indicates that the factors considered are not dependent, showing that the energy variation pattern is the same for both species. However, it was observed that the moisture content significantly affects the specific cutting energy (Table 2). 
Table 2. Summary of the analysis of variance for specific cutting energy $\left(\mathrm{J} . \mathrm{cm}^{-3}\right)$.

Tabela 2. Resumo da Análise de variância para Energia específica de corte $\left(\mathrm{J} . \mathrm{cm}^{-3}\right)$.

\begin{tabular}{lcccc}
\hline Cause of Variation & GL & Mean Square & F-value & p-value \\
Species (E) & 1 & $72.75^{\text {ns }}$ & 3.54 & 0.067 \\
Moisture (U) & 2 & $257.57^{\text {** }}$ & 6.27 & 0.004 \\
E x U & 2 & $118.27^{\text {ns }}$ & 2.88 & 0.068 \\
Error & 34 & 822.23 & - & - \\
EVC (\%) & - & 57.42 & - & - \\
\hline
\end{tabular}

*** significant at $5 \%$ of significance; $n . s=$ non-significant at $5 \%$ of significance; EVC = Experimental Variation Coefficient (\%).

The non-significant effect observed for the comparison of the specific cutting energy value between the species evaluated, takes into account all data for all moisture treatments, a value which was 6.5

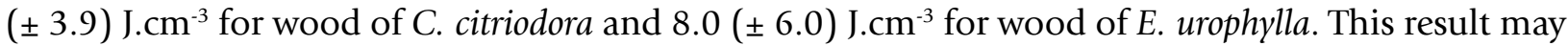
be related to wood density values near $0.72 \mathrm{~g} . \mathrm{cm}^{-3}$ for C. citriodora and $0.70 \mathrm{~g} . \mathrm{cm}^{-3}$ for E. urophylla.

The density is the main property studied as a predictor of cutting force during machining of wood. Usually positive relationships between these characteristics are expected to occur in the wood mechanical processing (EYMA et al., 2001; EYMA et al., 2001; KIVIMAA, 1950; MCKENZIE et al., 1999;). However, the density factor is not always sufficient to precisely explain the influence of wood on the cutting process, because there are exceptions related mainly to the specificities of the species. Eyma et al. (2004) evaluating the effect of some physical and mechanical properties on the cutting force of several tropical woods noted that wood density alone was not able to explain, with precision, the cutting forces during machining, and that the best results were obtained from the combination of density and some mechanical parameters. Melo et al. (2015), for C. citriodora wood, reported, that the cell wall fiber portion explained $93 \%$ of the cutting energy variation, which represented a $4 \%$ improvement compared to the prediction based on the wood density. Krilov (1980) stated that the presence of moisture in the wood significantly influences the tool behavior, and may interfere in the positive relationship of wood density with cutting force.

The highest specific cutting energy value was observed in equilibrium humidity wood $(12 \%)$. The dry wood $(0 \%)$ and the saturated wood $(75 \%)$ had statistically equal average cutting energy values (Figure 3).

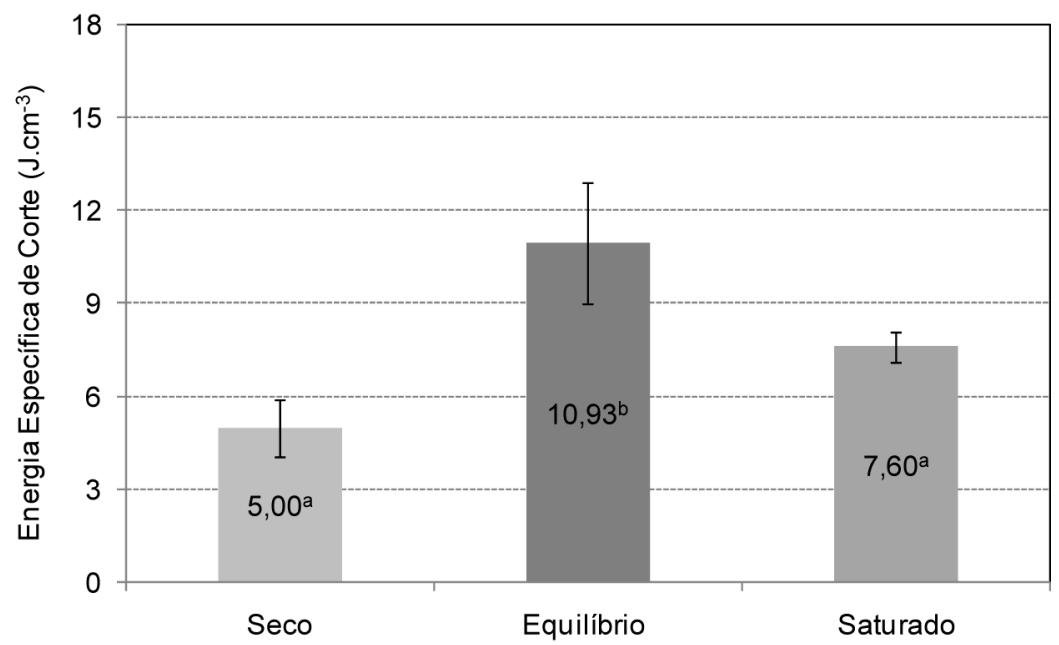

Figure 3. Average specific cutting energy consumption values and standard error bar among the moisture conditions established. Means followed by the same letter do not differ statistically by the Scott-Knott the 5\% test of significance $(p<0.05)$.

Figura 3. Valores médios do consumo da energia específica e barra de erro padrão entre as condições de umidade estabelecidas. Médias seguidas da mesma letra não diferem estatisticamente pelo teste de Scott Knott a $5 \%$ de significância $(p<0.05)$.

Lučić et al. (2004) and Moradpour et al. (2013) stated that the cutting of green wood always requires less cutting force than of dry wood, because the increased moisture reduces the magnitude of the wood mechanical characteristics, especially the resistance. It should be clear, however, that the authors assessed only two moisture conditions, those being the dry wood (moisture close to 12\%) and greenwood (moisture 40 to 70\%-above the fibre saturation point). As such, the results found in 
Nascimento et al. - Effect of moisture content on specific cutting energy

consumption in Corymbia citriodora and Eucalyptus urophylla woods

this present study (Figure 3) are in agreement with those reported by the authors cited, since a $44 \%$ increase was observed in the cutting energy for wood under moisture equilibrium (12\%) in relation to the saturated condition (75\%).

However, in this study, it was observed that the lowest specific cutting energy value was for the dry wood treatment. A 54\% and 34\% energy reduction was observed when compared to wood in moisture equilibrium and saturated, respectively (Figure 3). Unsal et al. (2003) and Korkut; Hiziroglu (2009) observed that when wood is subjected to different temperatures $\left(120^{\circ} \mathrm{C}, 150^{\circ} \mathrm{C}\right.$ and $180^{\circ} \mathrm{C}$ ), for 2 hours, 6 hours or 10 hours, the effect of the heat treatment significantly reduced the resistance of some mechanical properties of evaluated wood. For this present study, the wood was dried at a temperature of $103 \pm 2{ }^{\circ} \mathrm{C}$ for $48 \mathrm{~h}$, a fact that may have resulted in the least cutting resistance of the wood specimens, in the dry condition. Furthermore, the possibility that this resistance reduction can be related to small amount of specimens and, consequently the few cuts made, cannot be ruled out.

\section{CONCLUSIONS}

In general the specific cutting energy consumption of the longitudinal cut $\left(90^{\circ}-0^{\circ}\right)$ between the species did not show a statistically significant difference.

There was an increase of $44 \%$ in specific cutting energy consumption with the moisture reduction of $75 \%$ (saturated condition) to $12 \%$ (condition of equilibrium) and 54\% energy consumption reduction when the wood dried from $12 \%$ to $2 \%$ (dry condition) moisture.

In future work it is suggested using as many repetitions of the cuts in the dry condition and analysis of anatomical and chemical constituents of the cell wall.

\section{ACKNOWLEDGEMENTS}

The authors express their special thanks to Vallourec Florestal Ltda, Coordenação de Aperfeiçoamento de Pessoal de Nível Superior (CAPES) and Fundação de Amparo à Pesquisa do Estado de Minas Gerais (FAPEMIG), for supporting this experimental work. Finally, the authors thank the reviewers for their valuable comments and suggestions to improve the quality of this article.

\section{REFERENCES}

CHICHALA, D.; ORLOWSKI, K..A.; SANDAK, A.; SANDAK, J.; PAULINY, D.; BARANSKI, J.The effect of wood provenance and density on cutting forces while sawing scots pine (Pinussylvestris L.).Bioresources, v. 9, n. 3, p. 5349-5361, 2014.

EYMA, F; MEAUSOONE, P. J.; MARTIN, P. Strains and cutting forces involved in the solid wood rotating cutting process. Journal of Materials Processing Technology, v. 148, n. 2, p. 220-225, 2004.

EYMA, F; MEAUSOONE, P. J.; MARTIN, P. Influence of the transitional zone of wood species on cutting forces in the router cutting process (90-0). European Journal of Wood and Wood Products, HolzRohWerkst, v. 59, n. 6 , p. $489-490,2001$.

FRANZ, N. C. An analysis of the wood-cutting process. Ann. Arbor: University of Michigan Press, 1958. 600 p.

KIVIMAA, E. Cutting force in woodworking. Institute of Forestry Techenology Research, Helsinki, 1950.101 p.

KOCH, P. Wood machining process. New York: Ronald press company, 1964. $530 \mathrm{p}$

KORKUT, S.; HIZIROGLU, S. Effect of heat treatment on mechanical properties of hazelnut wood (Corylus colurna L.). Materials \& Design, v.30, n. 5 p. 1853-1858, 2009. 
KRILOV, A. Toward the re-appraisal of the influence of basic wood characteristics on sawblade potential. Holz als Roh- und Werkstoff, v. 38, p. 145-149, 1980.

LOEHNERTZ, S. P.; COOZ, I. V. Sawtooth forces in cutting tropical hardwoods native to South America. Washington: US Forest Service, 1998. 16 p. (Research Paper FPL-RP, 567).

LUČIĆ, R. B.; GOGLIA, V.; PERVAN, S.; DUKIC, I.; RISOVIC, S.The influence of wood moisture content on the process of circular rip-sawing. Part I: Power requirements and specific cutting forces. Wood Research, Kyoto, v. 49, n. 1, p. 41-49, 2004.

MELO, L. E. L.; SILVA, J. R. M.; Napoli, A.; LIMA, J. T.; NASCIMENTO, D. F. R. Influence of anatomical and basic density on the specific cutting force of the wood from Corymbia citriodora Hill \& Johnson. Forest Systems, v. 24, n. 3, 2015.

MCKENZIE , W. M.; KO, P.; CVITKOVIC, R.; RINGLER, M. Towards a model predicting cutting forces and surface quality in routing layered boards, in: INTERNATIONAL WOOD MACHINING SEMINAR, 14., 1999, Paris. Proceedings... Paris: CIRAD, 1999. p. 489-497.

MORADPOUR, P.; DOOSTHOSEINI, K.; SCHOLZ, F.; TARMIAN, A. Cutting forces in band saw processing of oak and beech wood as affected by wood moisture content and cutting directions. European Journal of Wood and Wood Products, HolzRoh Werkst, v. 71, n. 6, p. 747-754, 2013.

UNSAL, O.; KORKUT, S.; ATIK, C. The effect of heat treatments on some properties and colour in Eucalyptus camaldulensis Dehn. wood. Maderas. Ciencia y Technologia, Concepcion, v. 5, p. 145-152, 2003.

Recebido em 06/07/2016

Aceito para publicação em 13/10/2016

Sci. For., Piracicaba, v. 45, n. 113, p. 221-227, mar. 2017 DOI: dx.doi.org/10.18671/scifor.v45n113.22 
